\title{
Catchment management agencies as crucibles in which to develop responsible leaders in South Africa
}

\author{
MC Dent* \\ School of Agricultural, Earth and Environmental Sciences, University of KwaZulu-Natal, Private Bag X01 Scottsville 3209, South Africa
}

\begin{abstract}
During the past 17 years in South Africa, far-reaching policy, legislation and institutional changes in water-related governance have occurred. Responsible leaders have ensured that a paradigm of integrated water resource management (IWRM) is firmly entrenched in the above policy, legislation and institutional arrangements. IWRM in turn demands a level of interaction between individuals, disciplines and organisations such that multi-sector, multi-level stakeholders can collectively, timeously, wisely and cost-effectively visit the consequences of their proposed, present and past actions. Such social learning processes demand leadership and the ongoing development of leaders at all levels. This paper is structured around the propositions for leadership development in the field outlined by Scharmer (2009a). The principal aim of the paper is to reveal the extent to which the multi-sector catchment management agency (CMA) phenomenon is an ideal crucible for leadership development in the field. It is argued that the complex adaptive system that embodies the water realm needs to be engaged by developing complex adaptive systems of governance and that the CMAs have the potential to meet this requirement. Furthermore, it is argued that processes to achieve this required leadership are also ideal for developing leadership. At a time when worldwide developments in communication and computer technology have spawned an exponential growth in successful endeavours related to self-organising around common challenges, the CMA provides a unique and nourishing context for self-organising that simultaneously connects to South Africa's water governance mainstream of policies, laws, institutions and administrative procedures.
\end{abstract}

Keywords: leadership, integrated water resources management, self-organising, complex adaptive management

\section{Introduction}

Botswana, Zimbabwe, Mozambique, Swaziland, Lesotho and Namibia are inextricably linked with South Africa through shared river systems. Seventy per cent of the land area of the Southern African Development Community (SADC) region is comprised of shared river basins (Southern African Development Community, 2005). South Africa receives only half of the world average in terms of mean annual rainfall and the region's climate is highly variable and unpredictable. These factors, combined with a myriad of different topographies and soils, have created natural conditions for one of the world's most bio-diverse regions, (Wilderness Foundation South Africa, 2011). Overlain on this dynamic, interconnected template are enormous social challenges related to poverty, unemployment, health, and food security in the region. These challenges have placed significant additional complexity in the domain of all sectors of Southern African society. A connector of all of these challenges is water, which:

- Does not respect human boundaries

- Challenges our economic logic

- Is fundamental to survival of all living organisms

- Has nuisance (floods), infinite (droughts), spiritual and commodity value

- Is viewed differently by all sectors of society

- Is a common societal good and has no substitute

\footnotetext{
* To whom all correspondence should be addressed.

푱 +27 33 260-5730; fax: +27 33 260-6118; e-mail: dent@ukzn.ac.za

Received 8 June 2011; accepted in revised form 2 April 2012.
}

Given the interrelationships above, a plethora of organisations, policies, legislation, plans, strategies and perspectives are intimately involved in water-related matters, creating complex leadership challenges. Over the past 17 years, since 1994, far-reaching policy, legislation and institutional changes in water-related governance have occurred in South Africa. Responsible leaders have ensured that a paradigm of integrated water resources management (IWRM) is firmly entrenched in the above policy, legislation and institutional arrangements (DWAF, 1997). IWRM in turn demands a level of interaction between individuals, disciplines and organisations such that we can collectively, timeously, wisely and cost-effectively visit the consequences of our proposed, present and past actions. Furthermore, responsible leaders have determined that their responsibility in such circumstances will be to build multi-sector 'response-ability'; this can be inferred from the CEO Water Mandate (2010) and from DWAF (1997). This will mean developing the social learning crucible in which multi-stakeholder co-suspending, co-reflecting, co-sensing, co-prototyping of responses, and co-enacting is imperative for wise IWRM. There will naturally be much heat generated during such learning and without the crucible that is the multi-sector catchment management agency (CMA) to contain the processes there will be a strong tendency for them to disintegrate into chaos. This paper explores the leadership processes which develop the coordination practice fields, networks, virtual organisations, dialogue and interestbased bargaining crucibles for the generation of sociallyrobust knowledge to infuse IWRM processes, in such uncertain and dynamically complex environments. Socially-robust knowledge is knowledge which is trusted enough to engender 
societal action, sensu Nowotny et al. (2001), and is created by robust social processes.

This paper argues that it is inadequate to pursue leadership development to meet such challenges by analysing the gaps and then teaching aspects of leadership to fill those gaps. Furthermore the paper argues that the multi-stakeholder engagement spaces within catchment management agencies (CMAs), as prescribed in Chapter 7, of South Africa's National Water Act (Act No. 36 of 1998) (DWAF, 1998), are excellent crucibles in which to develop responsible leaders in the field of water and related matters in South Africa. This paper frames the above argument by drawing on the recent work of Scharmer (2009a), which outlines propositions for transforming the current leadership development paradigm into one which ignites a field of inspired connection and action. The extensive literature base that is presented in this paper offers implied support to Scharmer's views on leadership capacity development. Particularly relevant in this respect are papers by Baser and Morgan (2008) and Wigboldus et al. (2010).

\section{Massive institutional failure in the face of unprecedented challenges}

'We live in a world of massive institutional failure, a world that presents current and emerging generations of leaders with unprecedented challenges' writes Scharmer (2009a p. 2). 'How are the new generations of leaders in government, business, and civil society being prepared to deal with the profound economic, environmental, and social disruptions of our time?' he asks. He goes on to question: 'What resources and connections will help them, when thrown into the eye of the storm, to respond in innovative ways rather than resorting to the reactive responses of the past?'

In 1994, South Africa entered a new democratic era following the massive institutional failure of apartheid. During the 5 years which followed the first democratic elections in 1994, almost all of the national policies and laws of the past were fundamentally revised. The 1997 National Water Policy (NWP) and the 1998 National Water Act (NWA) were acclaimed worldwide as excellent and farsighted (BUSA, 2008). At their core was the need to address fundamental and far-reaching re-allocation of the country's water resources whilst preserving the economy and the environment and ensuring social justice. The new policy and legislation embraced integrated water resource management (IWRM) and the democratic concepts of continuous ongoing multi-stakeholder engagement in the processes of water management and allocation. These changes required new institutions, mindsets and behaviours in all major role players in government, business and civil society stakeholder sectors.

In the context of these legislated changes, there was really no turning back to practices of the past. The CEO Water Mandate (2010), in their Guide to Responsible Business Engagement with Water Policy, has stressed the importance of organisations outside of government engaging one another. In this sense the CEO Water Mandate (2010) tacitly provides strong endorsement of Chapter 7 of the NWA (1998), which deals with catchment management agencies (CMAs). Unfortunately, healthy, robust but graceful, direct multistakeholder engagement did not appear to happen (Colvin et al., 2011), for a variety of reasons, which are speculative and beyond the scope of this paper. So whilst with one set of lenses we see failure and the growth of the 'abscencing cycle' described by Scharmer (2009b) in his Theory U, with another set of lenses we see the potential for unimagined success in the 'presencing cycle' of the Theory $\mathrm{U}$, applied to multistakeholder social learning. This paper is essentially about the latter. The concept of the CMA, in which all sectors engage one another, is a deeply democratic one. This paper argues that the CMAs require leadership at all levels to bring them to life. That life will in turn nourish the leadership development processes to further grow the social learning in CMAs. Such virtuous feedback cycles are the essential message in Scharmer (2009a and 2009b). It is imperative for government, business and civil society to stimulate and nourish these processes. The feedbacks inherent in what is described above are true of all living, emergent phenomena which must themselves develop the processes and capabilities to grow themselves. In science, extensive use is made of metaphor to explain new concepts (McClintock, 2004; McClintock, 2003; Ravetz, 2003). An appropriate metaphor for this form of leadership development is the plant which must develop its own roots to anchor and feed itself, and must develop branches and leaves to harness its atmospheric needs; these then feed further growth. Wheatley (2006 p. 37) cites organisational theorist Weick (1979), who called attention to a similar process in organisations, what he termed 'enactment'. Weick noted that we participate in the creation of our organisational realities; 'the environment that the organisation worries about is put there by the organisation' (Weick, 1979 p. 152). Our CMAs need to be enacted into being by the same leadership processes which develop our IWRM leaders. For such development to take place we need, inter alia, to be aware of and avoid what Scharmer (2009a) refers to as a flawed leadership development model.

\section{Flawed leadership development model}

According to Scharmer (2009a), our current generations of leaders are poorly prepared to deal creatively with the major challenges of our time because the present mainstream approach to leadership development operates on a flawed model. He goes on to explain that the mainstream approach to leadership development is based on 'current skill deficits being assessed by so-called experts; people then engage individual-person-centric training courses, to fill these deficits and are surprised when those 'trained' individuals, are 'sucked back' into the old systems when they return to their institutions' (Scharmer, 2009a p. 2). Following on the above insights, Scharmer analysed the types of knowledge required by leaders and the intervention points which provided the context. These are presented in Table 1.

Scharmer (2009a) argues strongly that the future of leadership development is in the upper right corner of Table 1 . This is precisely where leaders at all levels in the whole process milieu of CMAs will need to be able to both develop and exercise their leadership. Such leaders will need to simultaneously form and be formed in the crucible that contains the multi-stakeholder engagement processes. The social learning processes which are emerging to nourish such growth will be discussed later in this paper. Scharmer is not alone in his call for new ways of developing leaders. Bammer (2005) presents a well-constructed argument for considering a new academic field named 'Integration and Implementation Science' to deal with phenomena such as diseases, poverty, alien invasive biota, crime, global climate change, ecosystem decay, biodiversity loss and river systems. The term phenomena is used in this paper to convey the notion of something which has multiple attributes and is experienced in multiple different ways by different 


\begin{tabular}{|c|c|c|c|}
\hline \multicolumn{4}{|c|}{$\begin{array}{c}\text { Table } 1 \\
\text { Leadership development matrix (Scharmer, 2009a p. 3) }\end{array}$} \\
\hline \multicolumn{4}{|l|}{ Type of knowledge } \\
\hline Intervention points & \begin{tabular}{|l|}
$\begin{array}{l}\text { Technical } \\
\text { knowledge } \\
\text { (technical skills) }\end{array}$ \\
\end{tabular} & $\begin{array}{l}\text { Relational } \\
\text { (stakeholder } \\
\text { coalition building) }\end{array}$ & \begin{tabular}{|l|} 
Transformational \\
self-knowledge \\
(identity, will)
\end{tabular} \\
\hline $\begin{array}{l}\text { Whole system } \\
\text { (multiple issues) }\end{array}$ & $\begin{array}{l}\text { System-wide } \\
\text { technical skill } \\
\text { building/training }\end{array}$ & $\begin{array}{l}\text { System-wide } \\
\text { relational capacity } \\
\text { building/training } \\
\text { (multi-stakeholder dialogue) }\end{array}$ & $\begin{array}{l}\text { System-wide } \\
\text { transformational } \\
\text { capacity building } \\
\text { (multi-stakeholder innovation) }\end{array}$ \\
\hline $\begin{array}{l}\text { Institution } \\
\text { (single issue) }\end{array}$ & $\begin{array}{l}\text { Institutional } \\
\text { technical skill } \\
\text { building/training }\end{array}$ & $\begin{array}{l}\text { Institutional } \\
\text { relational skill } \\
\text { building/training } \\
\text { (multi-stakeholder dialogue) }\end{array}$ & $\begin{array}{l}\text { Institutional } \\
\text { transformational } \\
\text { capacity building } \\
\text { (multi-stakeholder innovation) }\end{array}$ \\
\hline Individual & $\begin{array}{l}\text { Individual technical } \\
\text { skill building/training }\end{array}$ & $\begin{array}{l}\text { Individual relational } \\
\text { capacity } \\
\text { building/training } \\
\text { (multi-stakeholder dialogue) }\end{array}$ & $\begin{array}{l}\text { Individual } \\
\text { transformational } \\
\text { capacity building } \\
\text { (multi-stakeholder innovation) }\end{array}$ \\
\hline
\end{tabular}

actors and or observers. All of the aforementioned phenomena are found world-wide, are critical to sustainable development, and transcend human-made boundaries and cannot be engaged adequately within the confines of a single academic subject or organisational silo.

It is probable that Scharmer (2009a) had many examples in mind when he wrote, 'So why is the present, like the past, boxed into the lower left area of the grid?' He then proceeds to answer his own question, 'We are stuck in the old way of delivering leadership development for the same reason that Detroit got stuck building gasoline-guzzling cars: the sunk costs in existing methods, infrastructures, mindsets and capabilities' (Scharmer, 2009a p. 3).

\section{Stuck in the old way of delivering leadership development}

The 1994 change of government gave South Africans the opportunity to break from the past and create new systems, but also to bring in a substantial number of new leaders. It is undisputed that these changes were radical. At the same time it is imperative to understand the strong and irreversible trends that were already underway and which, in my opinion, would have eventually necessitated fundamental change. These forces have been given more visibility and more overt legitimacy in policy and legislation since 1994. These forces and trends are aptly described in the CEO Water Mandate (2010) and their acknowledgement in such a high profile publication makes it difficult to understand why the implementation of the 1998 NWA has resulted in only 2 of the potential 19 Catchment Management Agencies being constituted in the 13 years since 1998. This paper argues that one of key reasons for the slow transformation is the belief in the fallacy, borne out by government, business and civil society actions from 1998 to the present, that the new dispensation can come fully alive through command-and-control type administrative and management procedures whilst excluding social learning and leadership development processes.

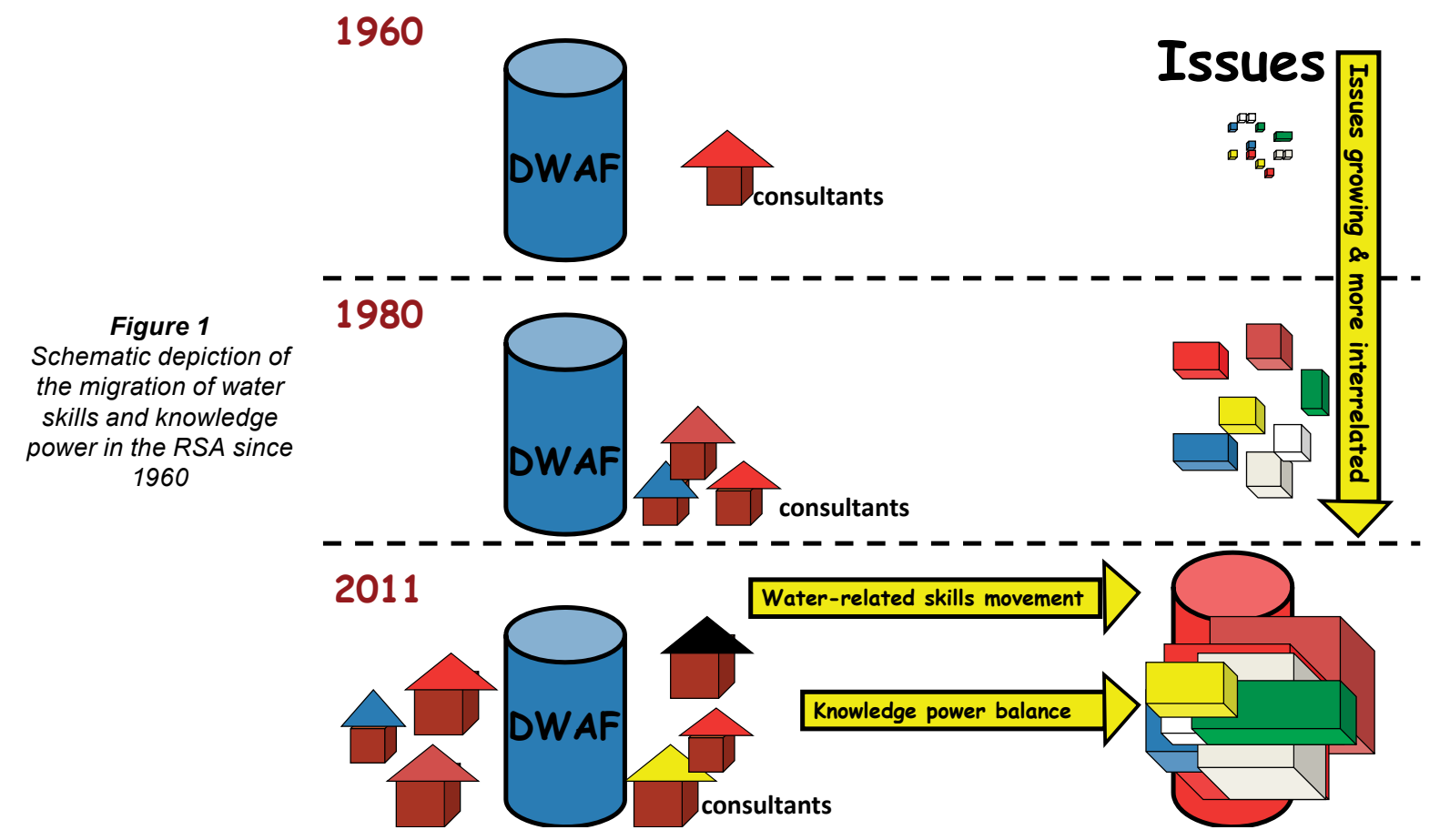


What follows is a brief outline of the historic forces which have led to the current forms of institutions, both, tangible and virtual, actual and potential. Before engaging this story it will be useful for readers to reflect on the words of Scharmer (2009a p. 3): 'Changing the approach from developing individual technical skills to transforming a system means that you need to reinvent everything, you need: new frames, new infrastructures, new people, new mindsets and new support structures. You also need new business models including funding mechanisms for participants who cannot afford to pay for it themselves but who are critical stakeholders in the respective microcosm of leadership learning.' The descriptions that follow indicate how all the above are happening in South Africa. The diagram below depicts 3 stages of the migration of skills which were articulated publicly for the first time in a DWAF/ UNESCO/WMO (1998) sponsored study, commissioned by the then Minister of Water Affairs and Forestry, Kader Asmal. The driver of change in this diagram is the growth in issues which the real world presents to us in the broad realm of water. A shortcoming of such a schematic depiction is that, in the real world, these issues are not neatly boxed and colour-coded. They manifest as integrated, complex, dynamic, adaptive systems phenomena.

In the 1960s, the DWA was effectively a large construction company, building dams, canals and pipelines in a supplydominated paradigm (Nomquphu et al., 2007). The Department's capacity to address wider hydrological and water quality issues was relatively small. The 'small-roofed building' in the diagram depicts a consulting firm. At the time, such firms had a relationship with the DWA for the purposes of helping the DWA to design and construct dams, canals and pipelines. During the 1980s the issues of water quality and quantity grew rapidly and the DWA responded by outsourcing to consultants. This created the start of an outflow of skills from the DWA to consultants, whose numbers and power grew. The bottom section of Fig. 1 depicts the current position in which the issues are large and integrated and stakeholder sectors such as mining, heavy industry (e.g. SASOL, ESKOM), forestry, sugar, local government in big cities, organised agriculture and conservation agencies have employed water resources expertise. In addition, the DWA is surrounded by dozens of consulting firms. The depleted skills in the DWA are quite naturally overwhelmed by the stakeholder sector demands which pull in all directions.

The creators of the 1998 National Water Act (NWA) foresaw this and skilfully crafted policy, legislation and institutional arrangements which, when wisely implemented, will enable the DWA (formerly the Department of Water Affairs and Forestry (DWAF) to stand in oversight above the situation and let the sectors reason with each other over allocation, water quality and other complex, dynamic issues which are fraught with uncertainty, tension and a paucity of information. Implicit in the CEO Water Mandate (2010) is the acknowledgement that the socio-scientific and socio-economic issues will be intensely researched and debated. A key question, therefore, is how does science and 'triple bottom line' economics (Elkington, 1997), serve the reasoning processes within the stakeholder sector interactions. Traditionally, science has served society by producing information and communicating it to society through books, journal articles and conference papers. There have also been a number of technological advances in the field of communications that have exponentially increased the forms of communication and lowered their costs. One consequence of lower transaction costs of communication has been that in democratic societies throughout the world there have consistently been indications of greater transparency in communicating information. South Africa is no exception in this respect. As sectors in society begin to contest their allocation of natural resources, the sectors have started to buy in expertise to assist them in the resource allocation contest. This development is depicted, schematically, in Fig. 2 below, which also depicts the phenomenon of the CMA. The CMA is not simply the CMA governing board, nor is it the employed staff, but is the whole 'engagement space' which encompasses all the stakeholder sectors and their employed and de facto advisors. The CMA phenomenon embodies the new frames, new infrastructures, new people, new mindsets, new support structures, and new business models of which Scharmer (2009a) writes. The CMAs

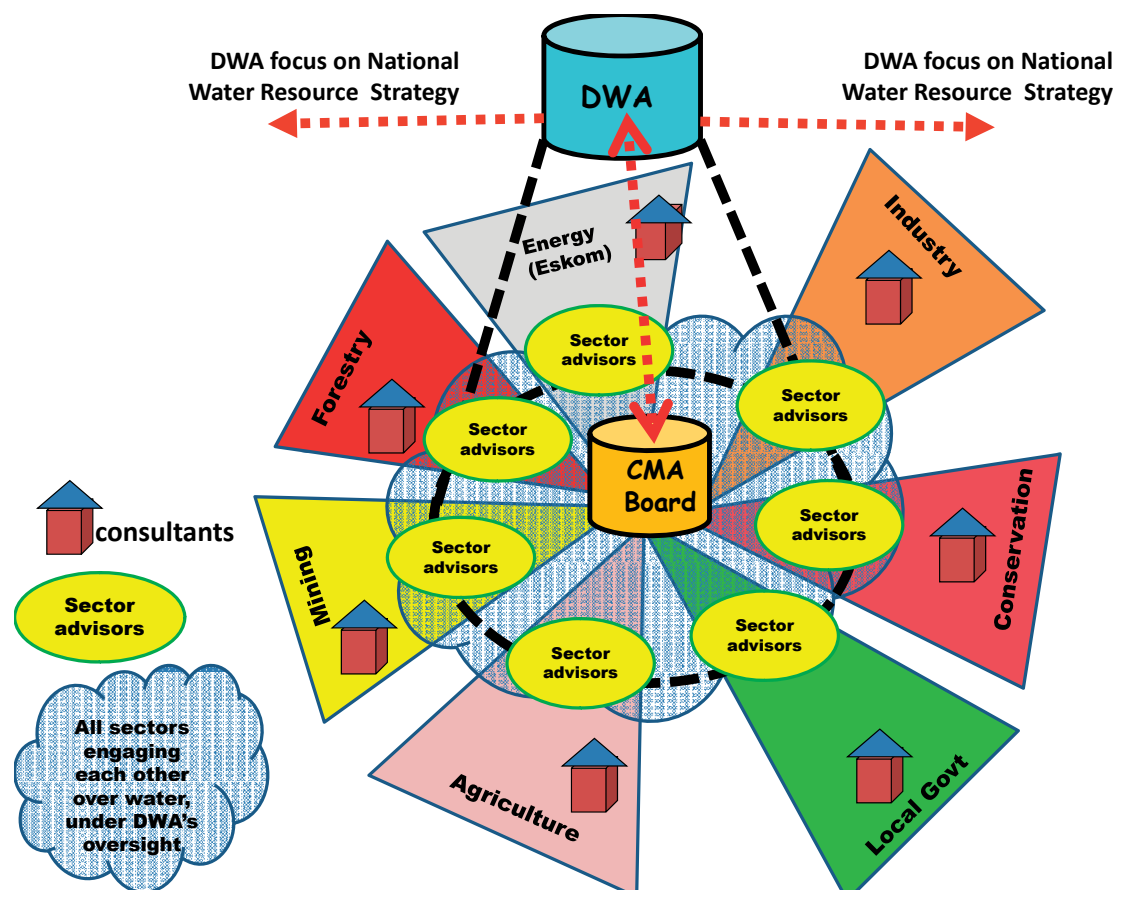

Figure 2

A depiction of the current configuration showing DWAF standing in oversight over the multi-stakeholder engagement processes in the CMA conceptual space 
also need to include funding mechanisms for previouslydisadvantaged sector participants who cannot afford to pay for it themselves but who are critical stakeholders as referred to by Scharmer (2009a). The follow-up processes to implement the 1998 NWA have designated that the Republic of South Africa be arranged into sector groupings and that these sectors come together in CMAs to democratically pursue IWRM within the constraints of the triple bottom line and under the oversight of the DWAF and the framework of the National Water Resource Strategy (NWRS), as depicted schematically in Fig. 2.

Each sector that is represented on a CMA governing board naturally has the right to supply its board member with scientific, economic, legal and social learning advice. It is in the intra- and inter-sector expertise realm, depicted in Fig. 3, in which these sector advisors interrelate, that the greatest leverage lies for real progress in integrated water resource management and for leadership development. The well- resourced sectors have already shown their hand in this regard. The forestry, mining, heavy industry, sugar, large city local government and conservation sector board members have the potential to be well served by advisors employed or contracted by these sectors. Such advisors are also key elements of the connection between the sector's CMA governing board member and all groupings in the sector. The UN Global Compact, CEO Water Mandate stresses that the role of these advisors within the organisations and sectors, at all levels, is vital (CEO Water Mandate, 2010). These advisors have relational responsibilities as well as functional responsibilities, which will be discussed later in this paper. Further impetus was given to the strategic theory that a guiding coalition of leaders at top level, both in the business and the scientific sense, is forming, by the announcement of the South African Water Partnership at COP17 (SABMiller, 2011). The aforementioned leaders, at the top level, are crucial as a guiding coalition in the IWRM processes. Their activities should be characterised by the behaviours listed in the 4 corners of Fig. 3.

The multi-stakeholder engagements will be primarily about the allocation of water use and water abuse (pollution). Water re-allocation, as with land re-allocation, is one of the fundamental tasks that post-apartheid South Africa needs to face. Allocation is a social process which requires: credible, trusted and shared understanding of information; generation of sensible and innovation options; shared understanding of consequences of decisions; acceptable decisions; wise decisions; equitable, peaceful, lasting and timely resolution (Ramalingam et al., 2008; Bruns, 2006; Innes, 2004; Spangler, 2003;

UNESCO-IHE, 2003; Warner, 2001; Innes and Booher, 1999; Moore, 1996; Fisher et al., 1991). In the light of these needs a key question that responsible leaders may ask is: 'How are credibility, trust, shared understanding, sensibility, acceptability, wisdom, equity and peace achieved?' To achieve the above, successful processes must offer regular, affordable and meaningful communication amongst all stakeholder representatives and their top-level scientific and other advisors and healthy open communication at and between all levels in the sectors. The processes must be flexible and iterative; must increasingly reveal more information on the system dynamics; must be open and transparent and enable implicit assumptions and mental models to be made explicit (Ramalingam et al., 2008; Bruns, 2006; Innes, 2004; Spangler, 2003; UNESCO-IHE, 2003; Warner, 2001; Innes and Booher, 1999; Moore, 1996; Fisher et al., 1991). Such processes need to be fostered by, and in turn will foster, generative leadership (Senge, 1990) and adaptive management. The processes need to incorporate and reflect the inputs of all stakeholders and contribute to and retain institutional memory (Baser and Morgan, 2008; Wigboldus et al., 2010). In southern Africa, such processes will need to incorporate a form of integrated systems simulation modelling which can function in a data-poor environment and overcome the barriers to communication between stakeholders which arise from geographic, disciplinary and organisational separation. Such processes are akin to those for participatory agent-based social simulation modelling described by Pahl-Wostl (2007); Pahl-Wostl (2002); and Pahl-Wostl and Hare (2004). Implicit in all these processes is a requirement to develop leadership skills and technology to enable the phenomena of inference, connectivity, credibility, trust, assumptions, perceptions, relationships and co-ordination to flourish.

Figure 3

Ideal behaviours in the anticipated community of practice of expert advisors to stakeholder sectors

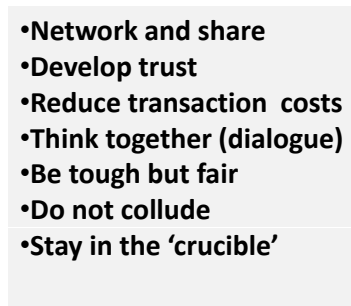

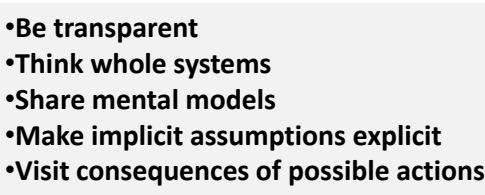

-Be transparent - Make implicit assumptions explicit -Visit consequences of possible actions 
It is in the above community of stakeholder sector advisors that the potential for self-organising systems, as described by Cundill and Fabricius (2010); Heylighen (2009); Wheatley (2006) and Dietz et al. (2003), needs to be realised, and this requires leadership at all levels. These self-organising communities will need to maintain frequent face-to-face communication and dense social networks that increase the potential for trust by allowing people to express and see emotional reactions to distrust. In this way the costs of supporting monitoring behaviour and inducing rule compliance are reduced (Putnam, 2001; Frank, 1988; Pretty, 2003; Burger et al., 2001; Weinstein, 2000).

One key purpose of this self-organising would be to develop and utilise water simulation modelling systems to act as repositories for the conversations and particularly the sequences of assumptions that make up the mental models of the stakeholders. In these self-organising endeavours the leaders at all levels would be wise to learn from the community modelling programs which are emerging as a result of the Open Modelling Interface (OpenMI) developments (Maidment, 2010). The Chesapeake Community Modelling Program (2010) is one of the more well known of these programs. In the field of knowledge and information, open-source endeavours have displayed exceptional performance and innovation for reasons outlined by Leadbeater (2009), Heylighen (2007) and Raymond (2001). The internet has lowered the transaction costs of cooperation and collaboration so dramatically that many open and semi-open phenomena, such as the Internet, Linux, PostGIS, MapWindows and OpenMI-Life, have emerged in the past 2 decades. All these open, self-organising endeavours subscribe to what is known as 'The Open Source Way', which is based on 5 central beliefs: open exchange, the power of participation, rapid prototyping, meritocracy and community (Chesapeake Community Modelling Programme, 2010). All of these beliefs are central to healthy social learning and require leadership to be exercised at all levels, across all sectors and across all generations. Could it be the 'The Open Way' that Dee Hock (quoted in Waldrop, 2007 p. 1) was thinking about when he said:

'We are at that very point in time when a 400 -year-old age is dying and another is struggling to be born -- a shifting of culture, science, society, and institutions enormously greater than the world has ever experienced. Ahead, the possibility of the regeneration of individuality, liberty, community, and ethics such as the world has never known, and a harmony with nature, with one another, and with the divine intelligence such as the world has never dreamed.'

Hock is the banker who, in 1975, developed the VISA credit card system which links over 20000 financial institutions and millions of retail organisations worldwide (Waldrop, 2007).
In the field of water and environmental matters the Open Way developments have been slower than those in business, where the open source software concepts were first deployed in the early 1970s (Waldrop, 2007). However, there has, in the last 8 years, been an acceleration in developments in water modelling and information systems. These have now converged to yield a plethora of OpenMI products, networks, communities and exceptionally large co-operative ventures (OpenMI-LIFE, 2010) whose results are accessible to all through the Open Way philosophy and Internet technology. The community of specialist advisors depicted in Fig. 3 needs to connect with the above-mentioned developments and to imbue all levels of intra- and inter-sector leadership with the generic lessons in them by using the social learning processes described in Figs. 7 to 9 . In addition to these are the matters of developing and retaining institutional memory, inter-operability standards, economies of scale, lowering communication transaction costs with both hard and soft systems approaches and developing a critical mass of knowledgeable people. All of these matters are explored in the extensive body of literature which is emerging on the Open Way (OpenMI-LIFE, 2010). This rapidly developing environment surrounding IWRM, when contained in the crucibles of the CMAs, will provide a rich variety of experiences and challenges for leadership development.

Scharmer (2009a) stresses the need for new business models, including funding mechanisms for participants who cannot afford to pay for it themselves but who are critical stakeholders in the respective microcosm of leadership learning. The CMAs are to be funded primarily by the stakeholder sectors themselves (DWAF, 1998), who will pay a so-called catchment management levy. The business models that emerge from this funding system will, hopefully, embrace the Open Way rather than the current expensive and fragmented government tendering way. As a result of these new business models the choice of a bargaining paradigm will surely fall on interest-based bargaining as outlined below and in Table 2 . The previously-disadvantaged sectors do not have the specialist advisors in the realms of science, economics, law or bargaining processes. Funding must be found from the state to support them. As with the well-resourced stakeholders this will have to be achieved in such a way that economies of scale and critical mass are optimised. Advisors will have to support their sector right across the country. The newly-formed Strategic Water Partners Network (SWPN) - South Africa, announced at COP17 (SABMiller, 2011), is a tangible step in the direction outlined above.

Interest-based bargaining will often result in the wellresourced stakeholders behaving in such a manner as to assist the poor with their information and knowledge (Rall, 1995).

\begin{tabular}{|l|l|}
\hline \multicolumn{2}{|c|}{ Comparing some of the attributes of rights and interest-based bargaining (after Rall, 1995) } \\
\hline Rights-based bargaining (lawyers) & Interest-based bargaining (leaders) \\
\hline Appropriate when only 2 parties and uncertainty is low & Appropriate when more parties and uncertainty is high \\
\hline Adversarial process & Co-operative process \\
\hline Stronger seeks to dominate the weaker & Stronger seeks to empower the weaker \\
\hline No sharing of information & Open sharing of information \\
\hline Large-scale duplication of effort & Productivity enhanced through sharing effort \\
\hline Difficult to reach decisions in uncertain environments & Easier to reach decisions in uncertain environments \\
\hline Expensive in terms of intellectual resources & Far better use of intellectual resources \\
\hline $\begin{array}{l}\text { State will have much difficulty ensuring fair deal for the } \\
\text { disadvantaged }\end{array}$ & $\begin{array}{l}\text { State can leverage (enlist) voluntary help of stakeholders to } \\
\text { empower disadvantaged }\end{array}$ \\
\hline Poaching of skills encouraged & Reduced incentive to poach skills \\
\hline
\end{tabular}


This assertion is also supported by Bruns and Meinzen-Dick (2006 p. 6), who are of the opinion that: 'Negotiation amongst disputants can often generate more creative and appropriate solutions than those imposed by a court or agency decision. Interest-based negotiation methods can help reframe bargaining in ways which better enable parties to achieve their goals, rather than being trapped by the zero-sum, win-lose assumptions of positional bargaining.'

It is evident that interest-based bargaining paradigms and behaviours are far more closely aligned to both the letter and the spirit of the 1997 National Water Policy and the 1998 National Water Act. A key question then is: What capacities need to be built to enable stakeholders to engage in interestbased bargaining? The brief discussion on the institutional needs and design principles to stimulate interest-based bargaining that follows will indicate that capable leadership is imperative and that the processes that underpin interest-based bargaining will also develop leadership.

Ostrom (1990) asserts that there is some evidence that if a small set of design principles are followed then any group that attempts to manage a common resource (e.g., aquifers, judicial systems, pastures) for optimal sustainable production can create institutions for collective action, which can overcome the problems of managing common resources. Ostrom's empirical approach sought to determine whether all populations overconsume and under-provide all common pool resources. Her work covered many different cultures all over the world and she found that some groups created contracts, agreements, incentives, constitutions, signals and media to enable cooperation for mutual benefit. The fact that Ostrom was recently awarded a Nobel Prize is testimony to the fact that her work is finding increasing resonance amongst top leaders, as natural resources become limiting and biodiversity loss and climate change issues become more urgent.

Social learning is central to self-organising systems that strive to manage common natural resources. The value of action research in social learning is emphasised by Bruns and Meinzen-Dick (1998 p. 11) who state: 'Action research approaches offer the most promising directions for learning and institutional innovation in water allocation.' The mental space provided by models and instant communications on the Internet are revolutionising social learning to support multiparty, interest-based bargaining. In this regard Bruns (2006 p. 1) believes that: 'Increased application of polycentric principles could open more pathways for solving collective-action problems and expand options for the creation and transformation of common property in water.' In conclusion, this section has emphasised the need for a break from the old ways of developing leadership in the water realm and at the same time it points the way to the future development needs and the context that will help to address these needs.

\section{'Leadership is the capacity of a system or a community to co-sense and co-create its future as it emerges'}

Scharmer, (2009a p. 4) makes the above statement about leadership as a phenomenon. The imperative to co-sense and co-create within the complexity, uncertainty and dynamism of catchment water systems is fundamental to healthy natural, social and economic systems in our shared catchments. Leadership which practices in, and is thereby also developed in, such a crucible, must engage challenges that require cosensing and co-creating on a continuous basis. The myriad complexities and sub-systems that make up life in a catchment make it imperative that outdated single-person-centric models of leadership development are transformed. As Scharmer (2009a p. 1) notes, we need to 'shift our framing of leadership development from building individual skills to igniting fields of inspired connection and action.' Unfortunately, in South Africa, transformation is so often narrowly misinterpreted to mean a change from White to Black in dominant positions, whereas systemic transformations such as those mentioned above are what is really required.

All organisations have functional responsibilities. Organisational plans and organograms record these. South Africa's catchments are inhabited by a plethora of organisations all of which have functional responsibilities. Taken collectively, these cover every conceivable function required. Why then are our rivers in the state that they are? What is missing? Could it be that our relational responsibilities are missing and hence our ability to co-sense and co-create co-responses is impaired?

South Africa's 1998 National Water Act and a plethora of similar acts in related areas are telling us that simply to commit all the required functions into organisational plans is not enough. Performing functional responsibilities alone will not ensure equity, environmental sustainability and economic efficiency in water resources management. To paraphrase Senge et al. (1995), one cannot know what it is to be human by looking at a list of the body parts and their functions. Human beings need to function in relation to others. As individuals we have relational responsibilities. So too, do organisations which are seeking the goal of integrated water resource management in a democratic framework of co-operative governance. South Africa's Constitution and 1998 NWA demand sound relational responsibility from organisations and this requires co-sensing and co-creating behaviours from leaders at all levels.

Water resources systems also constantly remind us of the need for co-sensing and co-creating because almost every problem is caused by somebody 'solving' their problem, in isolation, without full regard for the consequences. Consider the following examples: pesticide application and wash off; herbicide application and wash off; irrigation; fertiliser application and leaching; waste dumping and leaching or wash off; stormwater systems in cities; tarred roads and paving create excessive runoff peaks; overgrazing to solve pressing financial needs and wetland drainage to expand crop land. All these activities are primarily designed to solve problems and yet, in many cases, they create other, often more serious, problems downstream. The ironic part is that many of these problems are caused by people and organisations doing the functional part of their job well. The same cannot be said for their relational responsibilities in many instances. An inward focus, often created by a well-intended 'terms of reference' in a work contract, is ironically often the prime cause of this state of affairs: in other words, an individual and organisational mindset that restricts role players to the bottom left quadrant of Scharmer's diagram (Table 1). Fortunately, IWRM, if correctly understood and engaged, constantly forces leaders, at all levels, back into thinking in terms of system-wide transformational capacity building (multi-stakeholder innovation) in the top right hand block of Scharmer's diagram. The needs of IWRM are exceptionally important if one looks at them through the lens of a leadership development environment.

Referring back from the conceptual to South African operationalisation, developing the health of these relational responsibilities should be a primary goal of leaders at all levels in the phenomenon that is the CMA. The CMA's funds should 
not be used to carry out any of the functional responsibilities of the organisations which already exist in the catchment. The environment for leadership development within the CMA helps developing leaders to focus on relational interventions which ensure that the functional responsibilities of the stakeholder organisations complement each other; close gaps; develop economies of scale; avoid duplication; link up; consider systemic effects of actions; co-operate and co-ordinate activities.

In pursuing relational responsibilities the many leaders (at all levels) within the sectors that engage one another in CMA activities can learn from the team coach who seeks to achieve a sense of timing, a will to win, a sense of 'teamness', passion, flexibility, dedication, preparedness to go the extra mile, systemic insight into the bigger picture, anticipation, empathy, co-ordination, humility, pride in overall outcomes, caring, listening ability, timely responses, generosity, communication, understanding, motivation, sharing, openness, friendship and tenacity. All these are elements that help to develop the co-sensing and co-creating that one sees in a high-performing sports team as they exercise their relational responsibilities to integrate their functional responsibilities. In the old paradigm depicted in Fig. 4, the central DWA decided on the projects. These decisions typically took place within the silo of a particular division. A tender call followed, accompanied by the terms of reference which defined the boundaries of the work from an inward-looking perspective. The net result has been that nobody took explicit responsibility for the connections.

The powerful thing about having the whole system in the room is that the connections appear and there is no running away from them. Once again the key work of leaders is to reveal and deal with the relational connections.

\section{Putting field-based leadership development into practice requires going on a journey}

'The journey combines the personal, practical, systemic and innovation aspects of the design to create a roadmap of individual and collective transformation' Scharmer (2009a p. 4). There are numerous elements to the journey that Scharmer advocates and all are applicable to the leadership development journey within the multi-sector engagement space of CMAs.
This section concentrates on one of these journeys, namely, collective modelling endeavours and their role in guiding, stimulating, enriching and recording the conversations which surface stakeholder's assumptions and enable them to collectively consider the consequences of their assumption. If models are viewed in this paradigm they provide a repository for our scientific conversations and encourage us to make our implicit assumptions explicit. This is the real benefit of the modelling process as will be emphasised when the social learning models (Figs. 7 to 9) are discussed in relation to computer simulation models. To begin this discussion, consider Fig. 5, which is taken from a prominent DWAF 'internal strategic perspective' publication (DWAF, 2004). The figure indicates some of the connected activities which together make up IWRM. This figure and Figs. 7 and 8 are full and busy. They are meant to be this way to convey the notion that the real-life processes in the IWRM realm are many, complicated and complex.

The installed modelling system (bottom centre of the diagram) is of particular interest, as well as its relationship with the interactive development of options and recommendations, which is a central activity in the IWRM process. In the water management realm a vast body of literature is present on modelling matters (Singh and Frevert, 2006). Models occupy many specialist places in the broad arena of water science. In this paper the focus is placed on one aspect that is crucial to understanding models and particularly their role in leadership development within the context of IWRM. As their name states, models are not exact replicas of the real world. Models are simplified abstractions of the real world and as such are built from subjective mental models of how the real world works. Unfortunately, often by omission or design, some practitioners forget these assumptions and have come to view models as objective tools and often refer to a collection of models as a toolbox as depicted in Fig. 6. Such mental models reflect a machine view of the world which is exceptionally limiting when striving to cope with the complex, uncertain multi-stakeholder socio-ecological dynamic that characterises the catchment water realm. It is far more helpful and realistic to view these models as structured sequences of assumptions (Fig. 6). When these assumptions are openly declared and formalised, they can be explored along with their joint consequences

\section{Old paradigm}

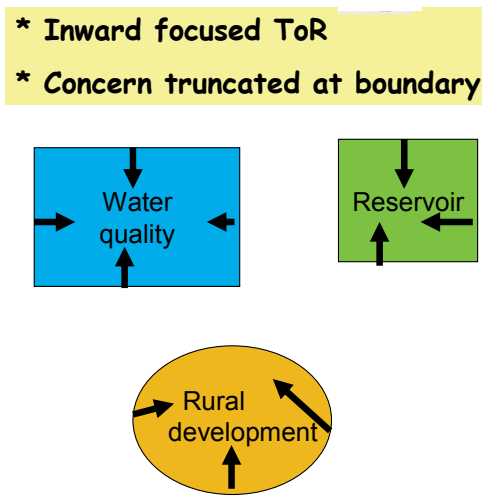

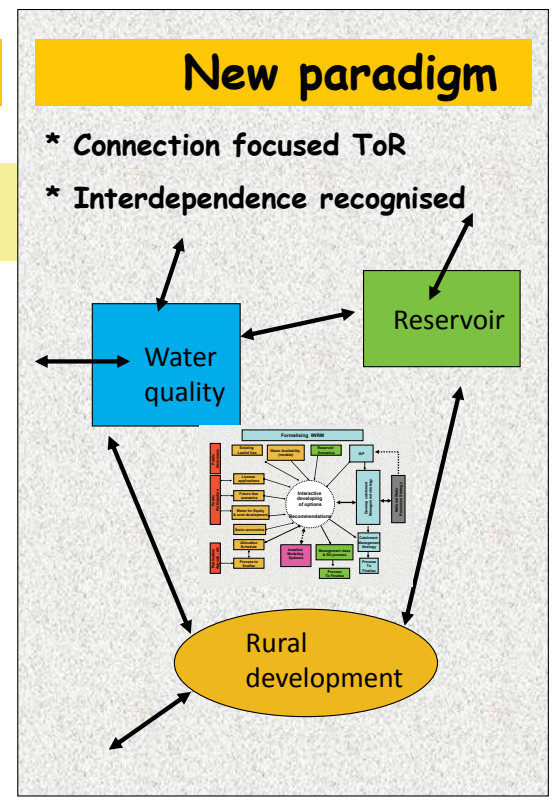

Figure 4

The paradigm change from silos to integration requires leadership to grow relational connections in IWRM activities 
Figure 5

Interactive developing

of options and

installed modelling

systems (after DWAF 2004)

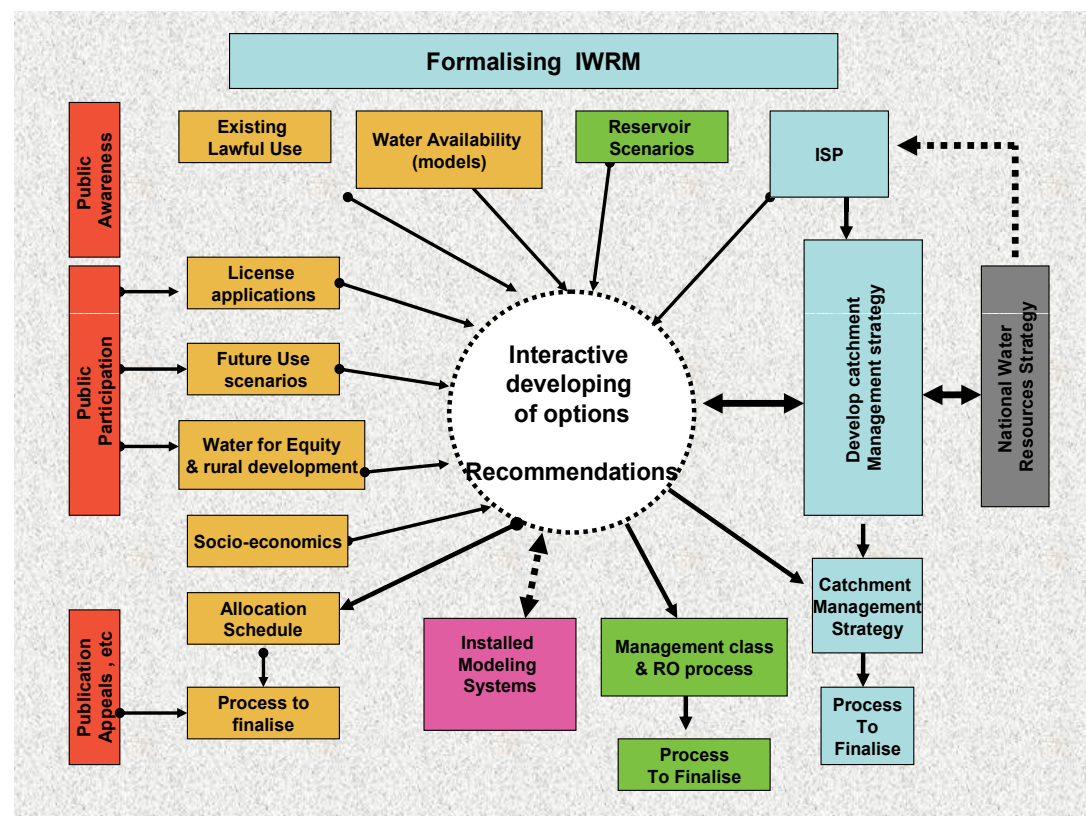

in a more holistic sense. In this way, socially-robust knowledge (Nowotny et al., 2001) emerges from the multi-stakeholder interactions. Socially robust knowledge is created by the same processes which build trust into the knowledge thus generated and it is this trust which greatly enhances the transference of this knowledge into wise action (Nowotny et al., 2001).

The active engagement of the deep, assumption-revealing and connecting conversations is crucial for wise, joint modelling. Such modelling provides the safe 'practice-fields' in which to explore win-win solutions and the potential consequences of intended actions. These are all activities which leaders should seek to engage in and which will at the same time develop leaders.

\section{Igniting a field of inspired connections}

'Leadership development is not about filling a gap but about igniting a field of inspired connections' (Scharmer, 2009a p. 5). What enabling infrastructures does it take to ignite a field of inspired connection and action? This paper argues that, in a sense, the physical connections are present since water is the connector. The required policy, legal and institutional infrastructure is now also present in South Africa. What remains is the relational connections, which need to be made by leadership at all levels. Scharmer (2009a p. 5) outlines several enabling conditions for these connections to be made to ignite the field. These are: '.. a diverse microcosm of players that mirrors the key stakeholders of the larger whole; deep-dive sensing journeys that take the group to the edges of a system, where they can experience it through the eyes of its marginalised stakeholders; rapid-cycle prototyping projects that provide safe practice fields to link the intelligence of the head, heart, and hand; a support infrastructure that helps to move the projects with the best results from the prototyping stage into the next stage of institutional innovation' (Scharmer, 2009a p. 5).

The combination of self-organising around allocation of commons and formal channels of power that effectively incorporate all of the above, make the CMA's engagement spaces so unique and imperative for our future. The developments described above and below in the social learning models are

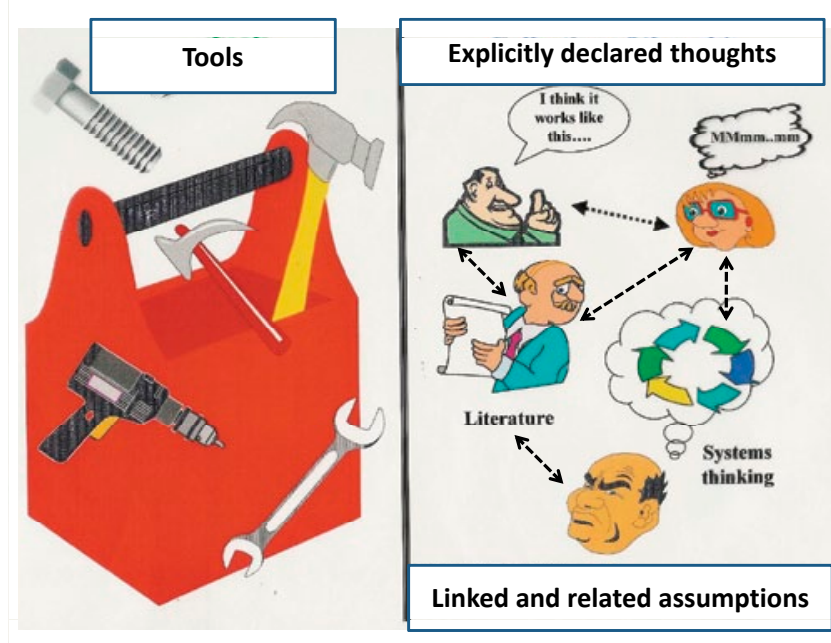

Figure 6

Modelling viewed as sequences of assumptions depicts science as a conversation

particularly encouraging when seen against the background of the rapidly-growing body of literature on the subjects of:

- Complex adaptive systems (Pahl-Wostl et al., 2007;

Muffatto and Faldani, 2003; Corning, 2002)

- Emergence (Dalke et al., 2007; Corning, 2002)

- Self-organising (Dietz et al., 2003; Heylighen and Gershenson, 2003; Susi and Ziemke, 2001)

- Stigmergic processes, which Heylighen (2007) and Susi and Ziemke (2001) explain as processes in which the work (ergon in Greek) done by one agent provides a stimulus (stigma) that entices other agents to continue the job

- Open access development systems (Maidment, 2010; Heylighen, 2007)

- Collective intelligence and leadership's role and development in the above (Uhl-Bien et al., 2007)

These are all beginning to impact on the discourse informing the emergence of the concept of reasoning support systems 

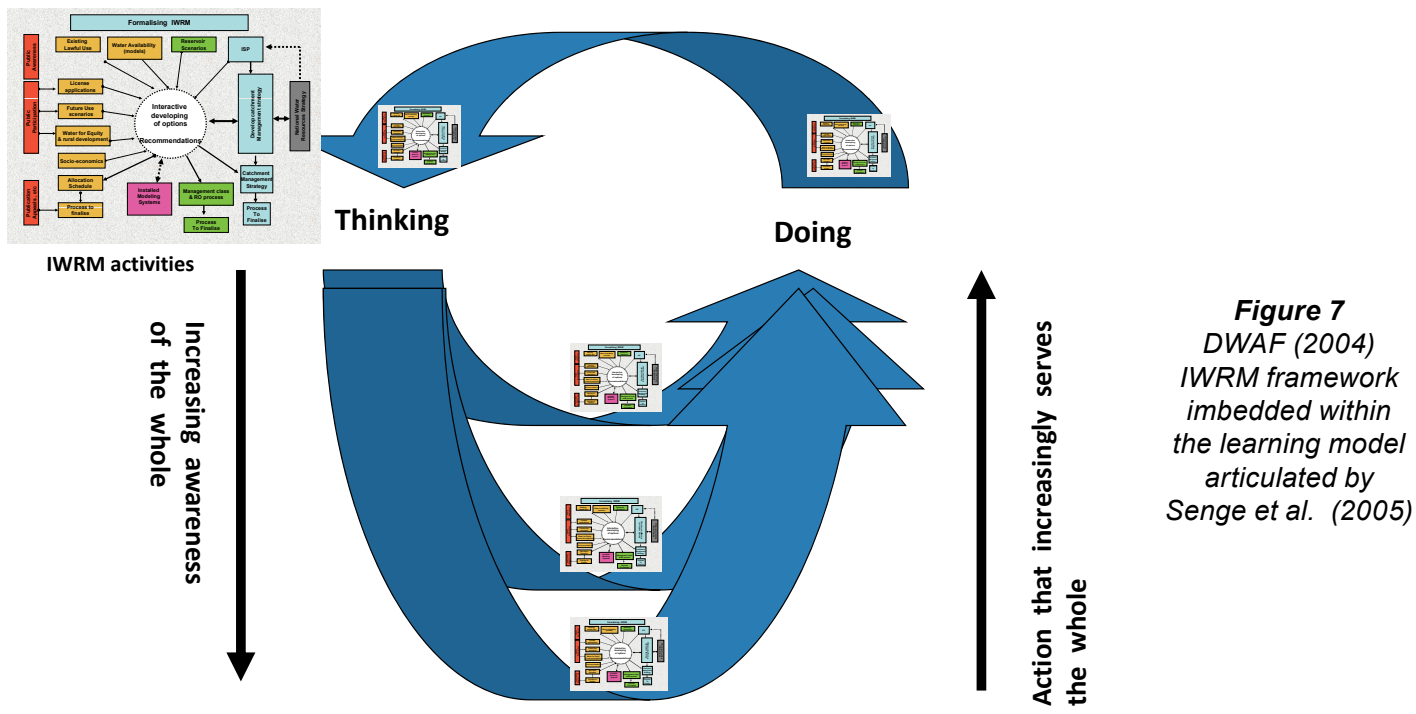

Deeper levels of learning create increasing awareness of the larger whole - both as it is and as it is evolving - and actions that increasingly become part of creating alternative futures.

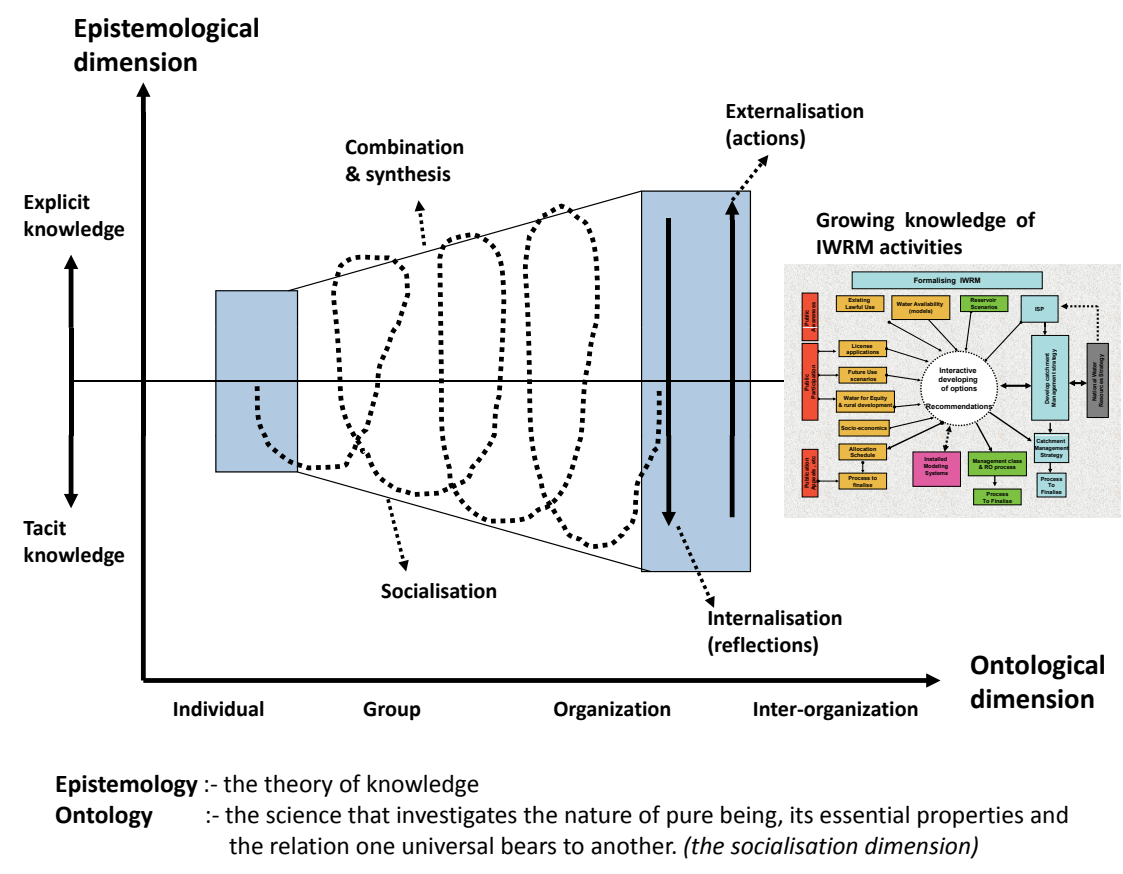

Figure 8 DWAF (2004) IWRM framework imbedded within the learning model articulated by Nonaka (2004)

in IWRM and the social learning frameworks (Figs. 7 to 9) to develop and support this reasoning. The repetition of the DWAF (2004) IWRM framework (Fig. 5) within the learning frameworks (Figs. 7 to 9) is to indicate that the focus of thinking and doing in each iteration is on growing the collective understanding of the focal subject. In this case the focus is on the DWAF (2004) IWRM framework (Fig. 5), but it could be any model that the multi-stakeholder, co-learning processes choose to focus on.

Nonaka's diagram emphasises the ontological dimension as our learning grows from individual through to inter-organisational, and the epistemological dimension which connects explicit and tacit knowledge. It shows how the ontological dimension assists in capturing more explicit knowledge and at the same time revealing more and more implicit knowledge about the phenomenon that the stakeholders are striving to jointly understand.
In Mintzberg's diagram, we once again see the importance of feedback, reflection, iteration and the place for theory, cases, experience and application in the processes of learning. The subject matter and simultaneously the context in this case is IWRM. The insights, influence and ability to keep the dynamic feedback loops going in all the above learning processes are those of leadership and these also simultaneously form the exercises for leadership development as they grow on themselves.

\section{New collaborative competence}

'The delivery of field-based leadership programs requires a new collaborative competence in order to customize and situate the programs in context' (Scharmer, 2009a p. 6). To develop such competence, Scharmer stresses the need for a commonlyperceived cross-sector challenge that is urgent, important and 


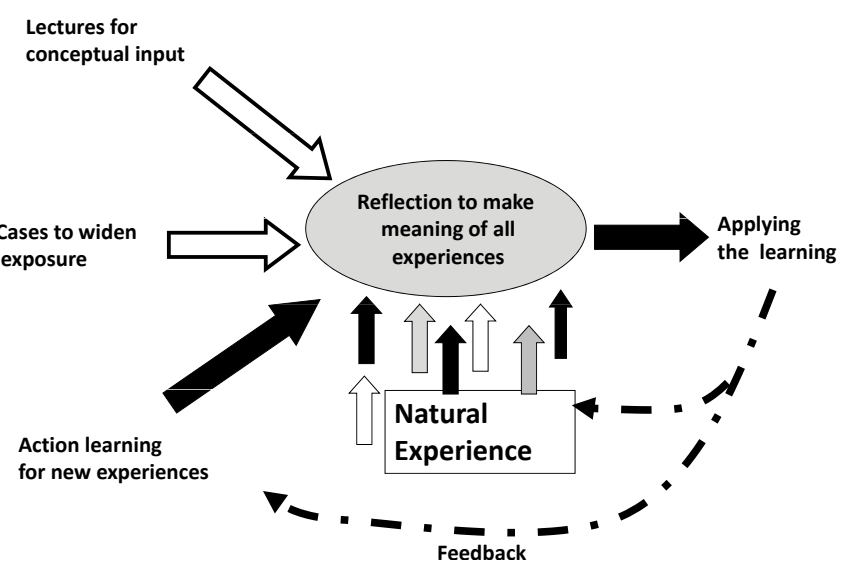

Figure 9

DWAF (2004) IWRM framework imbedded within the learning model articulated by Mintzberg (2004)

cannot be addressed in conventional ways of operating. Water provides just such a challenge in southern Africa. Water cuts across political, institutional, discipline and age boundaries. Decisions in the field of water cast a long shadow of consequences into the future and so, as Axelrod (2006) explains, this greatly increases the potential for co-operation. The imperative for new collaborative competence in the realm of water spans the space from the very top of organisations in government, business and civil society to local level. As Scharmer (2009a p. 6) states: 'It is always important to include frontline and community operators in order to make them real co-creators and partners in the multi-sector change effort.' It is difficult to think of a more ideal and challenging field-based leadership development realm than the CMAs, which combine the benefits of enabling systems for self-organising around allocation of commons, with formal channels of policy, legal and administrative power.

\section{Innovations in cross-sector infrastructures}

'Systems change requires innovations in cross-sector infrastructures' (Scharmer, 2009a p. 6). Prior to 1994, water management in South Africa experienced what Scharmer (2009a) would call a societal void and severe barriers that prevented profound positive change from taking place in IWRM. In the time period (1994-1998), intensive countrywide conversations resulted in the shared seeing and sensing of which Scharmer writes. These processes resulted in the formulation of the farsighted 1997 National Water Policy and 1998 National Water Act. This has been followed by a 13 -year period in which there were many individual and institutional ways of interpreting the implementation of the new policy. The sector, which is a natural societal grouping, emerged as the unit of engagement at CMA governing board level. The challenge now, for leadership at all levels, is to revive the shared seeing and understanding that will, in the words of Scharmer (2009a p. 7), 'enable the whole system to move very quickly from idea to action.'

South Africa is pregnant with potential in this regard and it is ripe for leadership to exploit this potential. To illustrate the extent of this potential consider the key elements of the book entitled Re-thinking Science Knowledge and the Public in an Age of Uncertainty (Nowotny et al., 2001), which addresses a transformation of society. South Africa has such a transforming and democratising society, a society which is moving beyond modernity to a realm in which society is characterised by pluralism, diversity and issues which transgress boundaries. The core of Nowotny et al.'s message is that there is a co-evolution of society and science, stimulated by the fact that the application of science has implications for society. These implications create conditions where the context speaks back, as they put it. 'Society speaks back' is particularly relevant to the application of science in the management of scarce natural resources wherein social learning is imperative and feedback is crucial to learning. This is leading to the transformation of knowledge institutions in which the emphasis has shifted from reliable knowledge to socially robust knowledge, i.e., knowledge which is trusted enough to engender societal action. Science has moved into what Nowotny et al. (2001) refer to as the 'Agora' (the Greek word for 'market place') - the market place of ideas. They make a most convincing case to show that expertise is now socially-distributed expertise, and no longer cloistered in universities and a few top consultancies or government departments. Previous sections of this paper address the forces driving this social distribution in South Africa, revealing that water stakeholder sectors now have substantial water science expertise either in-house or by hiring consultants. All this further enriches the CMAs as crucibles for leadership development because it is in this partially virtual, networked, complex adaptive organisational phenomenon that socially robust science is formed in the service of multi-stakeholder IWRM. On the book cover of Nowotny et al. (2001) Etzkowitz states: 'The authors take us beyond the dichotomies of science and society in their ovular new work, re-thinking science, into a new agora of interactive forces in which the old institutional boundaries of science, industry and government are transcended. Re-thinking science, re-thinks society.'

Wheatley and Frieze (2006) take up a similar theme when they write about the power of networks of relationships of people who share a common cause and vision. Wheatley and Frieze (2006) do however caution that simply forming networks is not sufficient. 'They need to evolve into intentional working relationships where new knowledge, practices, courage, and commitment can develop' (Wheatley and Frieze, 2006 p. 1).

\section{Focus on regenerating social systems}

'Given the disruptive challenges of our time, we see more and more situations in which leaders need to respond by operating from change levels that require reframing and regenerating, not only in terms of their personal and interpersonal skills but also in terms of their institutional and system designs' (Scharmer, 2009a p. 8).

In South Africa we are fortunate that the policy, legal and institutional aspects of the social system have been revised fundamentally since 1994. In the water and environmental fields the huge political changes provided the opportunity to bring about policy, legal and, in the case of behaviours relating to water management, institutional changes, that were then the envy of the world (BUSA, 2008). What has happened and is currently happening in South Africa are the kind of large-scale changes about which Scharmer writes. Clearly such situations cannot be artificially engineered in the university laboratory, or, for that matter, in society. They simply occur and surround the student of leadership, who is also an actor in the real-life drama. This paper has advanced the proposition that living, vibrant CMAs, in their broadest sense, form the crucible in which programmes of leadership can grow to address the blind spot, identified by Scharmer (2009a). 
Robust social-ecological knowledge creation requires robust, transparent, vibrant institutional forms and robust, transparent and vibrant engagement. Such institutional forms require at least a policy, legal and ethical framework. Why are institutions so important in the context of these changes? The following extract indicates an answer to this question: 'Today's world is shaped not by individuals alone, but by the networks of businesses and governmental and non-governmental institutions.' (Senge et al., 2008 p. 9).

The growth of complexity and uncertainty in society is driving the creation of more open systems of knowledge production (Nowotny et al., 2001). What would social-ecological scientists, who lead, need to study in such open systems of knowledge production and why should they be interested in the newly-generated social systems that are required for IWRM in CMAs? Informed by prior arguments in this paper it is suggested that they would need to study:

- How knowledge travels up from sector interactions in CMAs to Cabinet level in multi-sector settings.

- How knowledge travels sideways along sector lines from sector interactions in CMAs.

- How knowledge travels downwards to individuals and groups from sector interactions in CMAs.

- How IWRM reasoning and decision-making processes evolve in multi-sector settings.

- How the evolution of our understanding of water-related models from 'objective tools' to subjective sequences of assumptions, unfolds in multi-sector settings.

- How the integration of science and social science evolve as the assumptions in our models become the centre pieces of our reasoning and discourses.

- How interest-based bargaining begins to emerge to replace our current fixation on rights-based paradigms, in multisector settings.

- How alliances, resources and assistance patterns shift in response to interest-based bargaining paradigms being more widely adopted, in multi-sector settings.

- How knowledge inequities affect the emergence of sociallyrobust solutions in multi-sector settings.

- How uncertainty, risk and pressure affect individual, group and institutional behaviours in the IWRM process, in multi-sector settings.

None of the above can be learned from books or artificial creations in academic institutions. Universities need real-life institutional laboratories, which are effective crucibles filled with real tensions, fears, hopes and passions, in which to study and develop leadership capabilities in these realms.

Regenerating our current social systems to cope in the realm of complex adaptive systems requires leaders to truly understand the phenomenon of implementation and also of integration. This need motivated Bammer (2005) to write a seminal paper calling for consideration of a new academic discipline 'Integration and Implementation Science.' In a break from traditional academic views that look askance at implementation, Bammer (2005 p. 1) calls for researchers to collaborate and integrate across traditional boundaries, 'to bring together academic disciplines, and become more involved in the implementation of research in policy, product, and action.'

An interesting aspect of Bammer's paper is that it was born out of her work in epidemiology. In common with water, climate change, poverty, crime and invasive alien plants, diseases are phenomena that do not respect our humanly-conceived boundaries, both disciplinary and geographic, and continuously transcend them. These phenomena require that we enhance our leadership skills so that we can develop relationships, understanding and influence across boundaries of all manner and form. The combination of self-organising around allocation of commons and formal channels of power is what makes the CMA so unique and imperative for our future development of leaders for IWRM in southern Africa.

\section{Conclusions}

The South African water policy and law does not provide for an alternative to the CMAs as an organisational space, both virtual and real, for IWRM. The CMA is in fact unique in this regard in the whole environmental and natural resources management realm in the South Africa and in SADC. This uniqueness makes it a crucible to contain the social process of allocating entitlements to water use and 'ab-use'. Stakeholders in all sectors of South African society must engage in this organisational space. They have no other choice. In this sense the CMA mimics planet Earth and the individual human body as collective and individual leadership development crucibles, respectively. Humankind cannot run away from its collective leadership responsibilities to Earth and the individual cannot run away from leadership responsibilities to themselves.

The paper has outlined an emergent process which provides a real context which is exceptionally rich in challenges for leadership development and which includes the vital element of leadership having to build complex adaptive processes in addition to being part of such processes. The central place of water in environmental, social and economic spheres of life and its boundary spanning nature make it imperative that CMA leadership practice, at all levels, must be capable of self-organising to build networks of relationships that are vital to understanding and influencing the complex, dynamic and uncertain water realm. To assist with this understanding, leaders engage in dialogue, conversations and reflexive practice to build conceptual simulation models of the water systems. Key to the building of these models is the iterative process of revealing more and more implicit assumptions and mental models in the minds of the multiple stakeholders, about the water processes and their interrelationships. In the process of enabling, the above leaders at all levels, are challenged to utilise the sociallydistributed, diverse knowledge power to create new and innovative socially-robust knowledge systems that are capable of engendering wise collective action.

The problems we face are not ones that we can fight, flee or blame others for. They are problems that we have contributed to ourselves. It is imperative that we think, communicate and act differently as individuals and collectively. Leaders at all levels are called upon by the challenges of water to lead. After all, humankind has never been here before and so there are no administrative procedures or planning manuals, just an imperative to develop truly wise and responsible leaders. The Department of Water Affairs has given South Africans the policy, legislation and institutions for our crucibles of learning. We don't need anyone's permission to engage, except our own. We just need the courage to face ourselves in the mirror, then enter and stay in that crucible of learning.

\section{References}

AXELROD R (2006) The Evolution of Cooperation (Revised edn.). Perseus Books Group, New York.

BAMMER G (2005). Integration and Implementation Sciences: 
building a new specialization. Ecol. Soc. 10 (2) 6. URL: http:// www.ecologyandsociety.org/vol10/iss2/art6/ (Accessed 5 February 2007).

BASER H and MORGAN P (2008) Capacity, Change and Performance. Discussion Paper No 59B. European Centre for Development Policy Management (ECDPM), Maastricht.

BRUNS B (2006) Reconstituting water rights: pathways for polycentric praxis. Paper presented at: Survival of the Commons, Mounting Challenges and New Realities, Conf. International Association for the Study of Common Property, 19-23 June 2006, Bali, Indonesia

BRUNS B and MEINZEN-DICK R (1998) Negotiating water rights in contexts of legal pluralism: Priorities for research and action. Paper presented at: Crossing Boundaries, Conf. International Association for the Study of Common Property, 10-14 June 1998, Vancouver, Canada.

BUSA (2008) National Water Act: Parliamentary Review. Submission by Business Unity South Africa. URL: http://www.pmg.org.za/ files/docs/081022busa.doc (Accessed 13 January 2012).

CEO WATER MANDATE (2010) Guide to Responsible Business Engagement with Water Policy. URL: http://ceowatermandate.org/ files/Guide_Responsible_Business_Engagement_Water_Policy.pdf (Accessed 12 December 2011).

CHESAPEAKE COMMUNITY MODELLING PROGRAMME (2010) The CCMP Newsletter 3 (1). URL: http://ches.communitymodelling.org/CCMP-Newsletter-March-2010.html (Accessed 1 April 2010).

COLVIN J, GOSS J and DENT M (2011) CMA Expertise Development Network Deliverable 4: Synthesis report of the ICMA Watercourse and FETWater activities. Report to the WRC for Project No. K5/2033/1. Water Research Commission, Pretoria.

CORNING PA (2002) The re-emergence of 'Emergence': A venerable concept in search of a theory. Complexity 7 18-30.

CUNDILL G and FABRICIUS C (2010) Monitoring the governance dimension of natural resource co-management. Ecol. Soc. 15 (1) 15. URL: http://www.ecologyandsociety.org/vol15/iss1/art15/ (Accessed 15 August 2011).

DALKE AF, CASSIDY K, GROBSTEIN P and BLANK D (2007) Emergent pedagogy: learning to enjoy the uncontrollable - and make it productive. J. Educ. Change 8 111-130.

DIETZ T, OSTROM E and STERN PC (2003) The struggle to govern the commons. Science $\mathbf{3 0 2}$ 12. URL: http:// www.sciencemag.org (Accessed 12 November 2009).

DWAF (DEPARTMENT OF WATER AFFAIRS AND FORESTRY, SOUTH AFRICA) (1997) White Paper on a National Water Policy for South Africa. Department of Water Affairs and Forestry, Pretoria.

DWAF (DEPARTMENT OF WATER AFFAIRS AND FORESTRY, SOUTH AFRICA) (1998) National Water Act No.36 of 1998. Department of Water Affairs and Forestry, Pretoria.

DWAF (2004) Internal Strategic Perspective: Mvoti To Mzimkulu Water Management Area. Version 1: June 2004. Report No. P WMA 11/000/00/0304. Department of Water Affairs and Forestry, Directorate: National Water Resource Planning, Pretoria.

DWAF/UNESCO/WMO (1998) Mission on the Assessment of the Education and Training Needs of the Water Resources Management Services of the Republic of South Africa. Department of Water Affairs and Forestry, RSA, United Nations Educational, Scientific and Cultural Organization, and World Meteorological Organization. Department of Water Affairs and Forestry, Pretoria.

ELKINGTON J (1997) Cannibals with Forks: the Triple Bottom Line of 21 st Century Business. Capstone Paperback, Oxford.

FISHER R, URY W and PATTON B (1991) Getting to Yes: Negotiating Agreement Without Giving In ( $2^{\text {nd }} e d n$.). Penguin Books, New York.

FRANK R (1988) Passions within Reason: The Strategic Role of the Emotions. Norton, New York.

HEYLIGHEN F (1999) Collective intelligence and its implementation on the web. Comput. Math. Theor. Organ. 5 (3) 253-280.

HEYLIGHEN F (2007) Why is Open Access Development so Successful? Stigmergic organization and the economics of information. In: Lutterbeck B, Bärwolff M and Gehring RA (eds.).
Open Source Jahrbuch. Lehmanns Media. URL: http://pespmc1. vub.ac.be/Papers/OpenSourceStigmergy.pdf (Accessed 12 December 2011).

HEYLIGHEN F (2009) Complexity and self-organization. In: Bates MJ and Maack MN (eds.) Encyclopedia of Library and Information Sciences. CRC Press, Boca Raton.

HEYLIGHEN F and GERSHENSON C (2003) The meaning of selforganization in computing. IEEE Intell. Syst. 18 (4) 72-75.

INNES JE (2004) Consensus building; clarification for the critics. Plann. Theor. 3 (1) 5-20.

INNES JE and BOOHER DE (1999) Consensus Building and Complex Adaptive Systems: A Framework for Evaluating Collaborative Planning. J. Am. Plann. Assoc. 65 (4) 412.

LEADBEATER C (2009) We-think: Mass Innovation not Mass Production. Profile Books, London.

MAIDMENT DR (2010) Consortium of Universities for the Advancement of Hydrological Sciences (CUAHSI) Hydrologic Information System and OpenMI. Center for Research in Water Resources, University of Texas at Austin. European Commission and OpenMI Association, Brussels, 11-12 January 2010.

McCLINTOCK D, ISON RL and ARMSON R (2004) Conceptual metaphors: a review with implications for human understandings and systems practice. Cybernetics Human Knowing 11 (1) 2547.

McCLINTOCK D, ISON RL and ARMSON R (2003) Metaphors of research and researching with people. J. Environ. Plann. Manage. 46 (5) 715731

MINTZBERG H (2004) Managers Not MBAs: A Hard Look at the Soft Practice of Managing and Management Development. BerrettKoehler Publishers, San Francisco. 464 pp.

MOORE CW (1996) Negotiation. US Army Engineers Institute for Water Resources, IWR Report 96-R-21. URL: www.au.af.mil/ au/awc/awcgate/army/usace/negotiation.htm (Accessed 25 March 2011).

MUFFATTO M and FALDANI M (2003) Open source as a complex adaptive system. Emergence 5 (3) 83-100.

NOMQUPHU W, BRAUNE E and MITCHELL S (2007) The changing water resources monitoring environment in South Africa. S. Afr. J. Sci. 103 (7-8) 306-310.

NONAKA I (2004) A dynamic theory of organizational knowledge creation. Chapter 9. In: Starkey K, Tempest S and McKinlay A (eds.). How Organizations Learn. Thomson Learning, London. $618 \mathrm{pp}$.

NOWOTNY H, SCOTT P and GIBBONS M (2001) Re-thinking Science Knowledge and the Public in an Age of Uncertainty. Polity Press, London. 278 pp.

OPENMI-LIFE (2010) Integrating Models and Policy - OpenMI Solutions for a Sustainable Future. OpenMI-Life Final Workshop. Brussels, Belgium. URL: http://www.openmi-life.org/events/finalworkshop.php (Accessed 13 January 2012).

OSTROM E (1990) Governing The Commons: The Evolution of Institutions for Collective Action. Cambridge University Press, Cambridge. $271 \mathrm{pp}$.

PAHL-WOSTL C (2007) The implications of complexity for integrated resources management. Environ. Model. Softw. 22 561-569.

PAHL-WOSTL C (2002) Towards sustainability in the water sectorThe importance of human actors and processes of social learning. Aquat. Sci. 64 394-411.

PAHL-WOSTL C and HARE M (2004) Processes of Social Learning in Integrated Resources Management. J. Community Appl. Soc. Psychol. 14 193-206.

PAHL-WOSTL C, CRAPS M, DEWULF A, MOSTERT E, TABARA $\mathrm{D}$ and TAILLIEU T (2007) Social learning and water resources management. Ecol. Soc. 12 (2) 5. URL: http://www.ecologyandsociety.org/vol12/iss2/art5/ (Accessed 2 July 2010).

PRETTY J (2003) Social capital and the collective management of resources. Science 302 (5652) 1912-1914.

PUTNAM R (2001) Bowling Alone: The Collapse and Revival of American Community. Simon and Schuster, New York. 515 pp.

RALL PJ (1995) Negotiation. Master of Business Leadership, $3^{\text {rd }}$ year lecture notes. School of Business Leadership, University of South Africa.

RAMALINGAM B, JONES H, REBA T and YOUNG J (2008) 
Exploring the science of complexity:- Ideas and implications for development and humanitarian efforts. Working Paper 285, $\left(2^{\text {nd }}\right.$ edn.). Overseas Development Institute (ODI), London.

RAYMOND ES (2001) The magic cauldron. Chapter 5. In: The Cathedral and the Bazaar. O'Reilly On-line. URL: http://oreilly. com/catalog/cathbazpaper/chapter/ch05.html (Accessed 12 December 2011).

RAVETZ J (2003) Models as metaphors. Chapter 3. In: Kasemir B, Jager J, Jaeger CC, Gardner MT (eds.) Public Participation in Sustainability Science. A handbook . Cambridge University Press, Cambridge.

SABMILLER (2011) SA Government and Private Sector Form Water Partnership at COP17. Announcement at COP17, Durban, South Africa. URL: http://www.sabmiller.com/index. asp?pageid $=32$ \&newsid $=1778$ (Accessed 15 January 2012).

SCHARMER CO (2009a) Leadership development is not about filling a gap but about igniting a field of inspired connection and action; ten propositions on transforming the current leadership development paradigm. Paper prepared for: Round Table Meeting on Leadership for Development Impact. The World Bank Institute, Washington, DC, September 27-28, 2009. Draft 1.1 (revised 5 October, 2009)

SCHARMER CO (2009b) Theory U: Leading from the Future as it Emerges. Berrett - Koehler, San Francisco. 462 pp.

SENGE PM (1990) The leader's new work: building learning organisations. Sloan Manage. Rev. 32 (1) 7-23.

SENGE PM, ROBERTS C, ROSS RB, SMITH BJ and KLEINER A (1995) The Fifth Discipline Fieldbook: Strategies and Tools for Building a Learning Organisation. Nicholas Brealey, London. 593 pp.

SENGE PM, SCHARMER CO, JAWORSKI J and FLOWERS BS (2005) Presence: Exploring Profound Change in People, Organisations and Society. Nicholas Brealey, London. 289 pp.

SENGE PM, SMITH B, KRUSCHWITZ N, LAUR J and SCHLEY S (2008) The Necessary Revolution: How Individuals and Organizations are Working Together to Create a Sustainable World. Nicholas Brealey, London.

SINGH VP and FREVERT D (2006) Watershed Models. CRC Press Taylor \& Francis Group, Boca Raton. URL: http://www.ce.metu. edu.tr/ ce530/Watershed\%20Models.pdf (Accessed 15 January 2012).

SOUTHERN AFRICAN DEVELOPMENT COMMUNITY (SADC) (2005) Regional Water Policy. URL: http://www.unep.org/dams/ files/Country\%20Dialogues/SADCRegionalWaterPolicy.pdf (Accessed 12 December 2011).

SPANGLER B (2003) Integrative or interest-based bargaining. In: Burgess $\mathrm{G}$ and Burgess H (eds.). Beyond Intractability. Conflict
Research Consortium, University of Colorado, Boulder. URL: http://www.beyondintractability.org/essay/interest-based bargaining (Accessed 8 November 2010).

SUSI T and ZIEMKE T (2001) Social cognition, artefacts and stigmergy. Cognitive Syst. Res. 2 (4) 273-290.

TURTON AR (2008) Three strategic water quality challenges that decision-makers need to know about and how the CSIR should respond. Keynote Address: A Clean South Africa, CSIR Conference, 18 November 2008 Pretoria. CSIR Report No. CSIR/ NRE/WR/EXP/2008/0160/A. CSIR, Pretoria.

UNESCO-IHE (2003) Conflict Prevention and Cooperation in International Water Resources Course Book. URL: http://unesdoc.unesco.org/images/0013/001333/133312e.pdf (Accessed 15 January 2011).

UHL-BIEN M, MARION R and MCKELVEY W (2007) Complexity Leadership Theory: Shifting leadership from the industrial age to the knowledge era. Leadership Q. 18 298-318.

WALDROP MM (2007) The Trillion-Dollar Vision of Dee Hock. URL: http://www.fastcompany.com/magazine/05/deehock.html (Accessed 21 November 2009).

WARNER M (2001) Complex Problems... Negotiated Solutions: The Practical Applications of Chaos and Complexity Theory to Community-based Natural Resource Management. ODI, London.

WEICK K (1979)The Social Psychology of Organization. Random House, New York. 152 pp.

WEINSTEIN MS (2000) Pieces of the puzzle: solutions for community-based fisheries management from native Canadians, Japanese cooperatives, and common property researchers. Georgetown Int. Environ. Law Rev. 12 375-412.

WHEATLEY MJ (2006) Leadership and the New Science: Discovering Order in a Chaotic World. Berrett-Koehler Publishers, San Francisco. $218 \mathrm{pp}$

WHEATLEY MJ and FRIEZE D (2006) How Large-Scale Change Really Happens - Working With Emergence. The School Administrator Spring 2007. URL: http://www.margaretwheatley.com/ articles/largescalechange.html (Accessed 12 December 2011).

WIGBOLDUS S, NELL AJ, BROUWER H and VAN DER LEE J (2010) Making Sense of Capacity Development. Discussion paper for the seminar on International Capacity Building - Recipes for Success, 28 January 2010, The Hague. Wageningen UR Centre for Development Innovation, Wageningen.

WILDERNESS FOUNDATION SOUTH AFRICA (2011) Biodiversity Briefing Series 3. URL: http://www.wildernessfoundation.co.za/index.php?option $=$ com content $\& v i e w=$ article $\&$ id $=$ 33:biodiversity-briefing-series-biodiversity-as-a-resource-fordelivering-watery\&catid=16:resources\&Itemid=29 (Accessed 12 December 2011). 